\title{
Ultra Vires Kewenangan Kemenkumham sebagai Pengadilan Non-Litigasi dalam Sistem Ketatanegaraan Indonesia
}

\author{
Ahmad Gelora Mahardika \\ Hukum Tata Negara Institut Agama Islam Negeri Tulungagung, Tulungagung \\ Email : geloradika@gmail.com
}

Info Artikel:

| Diterima: 02 April 2019

| Disetujui: 28 Juni 2019

| Dipublikasikan: 02 Juli 2019

\begin{abstract}
The decision of the Constitutional Court Number 56 / PUU-XIV / 2016 revoked the power for the Government to recall a Regional Regulation and hand over the authority to the Supreme Court. However, the Government through the Ministry of Law and Human Rights then issued Regulation of the Minister of Law and Human Rights No. 32 of 2017 concerning Procedures for Settling Disputes in Legislation through the Non-litigation Path which in principle provided permits to support the Directorate General of Regulation. Initially this authority did not exist in the Minister of Law and Human Rights Regulation of the Republic of Indonesia Number 29 of 2015 concerning Organization and Work Procedure of the Ministry of Law and Human Rights of the Republic of Indonesia, but then the authority was regulated in Republic of Indonesia Minister of Law and Human Rights Regulation Number 24 Year 2018 Regarding the Third Amendment to the Regulation of the Minister of Law and Human Rights Number 29 of 2015 concerning the Organization and Work Procedure of the Ministry of Law and Human Rights of the Republic of Indonesia. The extension of authority is being unconstitutional, it was also stipulated by law, this authority was also previously owned.
\end{abstract}

Key words : authority,nonlitigation, constitution

\begin{abstract}
Abstrak
Putusan Mahkamah Konstitusi Nomor 56/PUU-XIV/2016 mencabut kewenangan bagi Pemerintah untuk membatalkan Perda dan menyerahkan kewenangan tersebut kepada Mahkamah Agung. Akan tetapi, Pemerintah melalui Kementerian Hukum dan HAM kemudian justru menerbitkan Peraturan Menteri Hukum dan HAMNomor 32 Tahun 2017 tentang Tata Cara Penyelesaian Sengketa Peraturan PerundangUndanganMelalui Jalur Nonlitigasi yang memberikan kewenangan tambahan bagi Direktorat Jenderal Peraturan Perundang-undangan untuk menyelesaikan sengketa peraturan perundang-undangan. Pada awalnya kewenangan tersebut tidak ada di dalam Peraturan Menteri Hukum Dan Hak Asasi Manusia Republik Indonesia Nomor 29 Tahun 2015 Tentang Organisasi Dan Tata Kerja Kementerian Hukum Dan Hak Asasi Manusia Republik Indonesia, namun kemudian kewenangan tersebut diberikan dalamPeraturan Menteri Hukum dan HAM RI Nomor 24 Tahun 2018 Tentang Perubahan Ketiga Atas Peraturan Menteri Hukum Dan Hak Asasi Manusia Nomor 29 Tahun 2015 Tentang Organisasi Dan Tata Kerja Kementerian Hukum Dan Hak Asasi Manusia Republik Indonesia. Perluasan kewenangan ini mempunyai potensi inkonstitusional karena tidak sesuai dengan putusan MK, selain itu kewenangan ini juga diadakan sebelum kewenangan tersebut diberikan secara hukum.
\end{abstract}

Kata Kunci : Kewenangan, Nonlitigasi, Konstitusi 


\section{A. PENDAHULUAN}

Putusan Mahkamah Konstitusi Nomor 56/PUU-XIV/2016 tanggal 15 Juni 2017 yang membatalkan kewenangan Pemerintah untuk membatalkan Perda membuat secara hukum di Indonesia saat ini hanya Mahkamah Agung yang mempunyai kewenangan melakukan review terhadap Peraturan Daerah Provinsi ataupun Kab/Kota. Akan tetapi, ternyata pada tanggal 8 Desember 2017, Menteri Hukum dan HAM RI mengesahkan Peraturan Menteri Hukum dan HAM Nomor 32 Tahun 2017 tentang Tata Cara Penyelesaian Sengketa Peraturan Perundang-Undangan Melalui Jalur Nonlitigasi yang memberikan kewenangan kepada Menkumham melalui Direktur Jenderal Peraturan Perundang-undangan

untuk membentuk Tim yang bertugas melakukan penyelesaian sengketa di luar pengadilan. Sengketa yang dimaksud adalah konflik/pertentangan antar norma hukum, atau konflik kewenangan yang timbul karena berlakunya peraturan perundang-undangan. ${ }^{1}$

Sejak era reformasi, hukum menjadi salah satu sektor yang menjadi prioritas agenda reformasi. Reformasi hukum menjadi vital dikarenakan sejak era orde baru hukum menjadi alatlegitimasi kekuasaan dan komoditas politik penguasa. Kondisi tersebut bukanlah hal yang aneh, politik otoriter yang berbalut demokrasi prosedural pada akhirnya menghasilkan produk hukum konservatif. ${ }^{2}$ Masyarakat cenderung apatis dan pada akhirnya penguasa semakin semena-mena sejalan dengan minimnya pengawasan.

Reformasi peradilan diawali dengan mengembalikan kewenangan mengadili yang sebelumnya terpisah di sejumlah lembaga negara, dijadikan dibawah satu atap yaitu Mahkamah Agung. Semangat itu diawali dengan TAP MPR X/MPR/1998 yang

\footnotetext{
${ }^{1}$ Diktum Menimbang dalam Peraturan Menteri Hukum dan HAM Nomor 32 Tahun 2017 tentang Tata Cara Penyelesaian Sengketa Peraturan PerundangUndangan Melalui Jalur Nonlitigasi

2 Mahfud MD Moh,Politik Hukum di Indonesia,(Jakarta:PT.Raja Grafindo Persada,2010)
}

kemudian ditindaklanjuti dengan UU No 35 Tahun 1999Tentang Ketentuan-Ketentuan Pokok Kekuasaan Kehakiman. Menurut Undang-Undang tersebut, urusan organisasi, finansial, dan administratif dari pengadilan harus berada di bawah Mahkamah Agung. Proses pengalihan tersebut dilakukan secara bertahap dalam tempo paling lama 5 tahun. Proses satu atap menjadi sempurna dengan lahirnya Undang-Undang Nomor 4 Tahun 2004 tentang Kekuasaan Kehakiman. Sejak terbitnya Undang-Undang Nomor 4 Tahun 2004 tentang Kekuasaan Kehakiman praktis semua Badan Peradilan baik yang sebelumnya berada di Departemen Agama, Departemen Kehakiman ataupun Departemen Pertahanan sekarang berada dibawah satu atap yaitu Mahkamah Agung.

Terkait dengan kewenangan menguji peraturan perundang-undangan di bawah undang-undang, pasal ini memberikan kekuasaan mutlak bagi Mahkamah Agung untuk menguji peraturan perundang-undangan dibawah undang-undang. Hal ini sesuai dengan ketentuan dalam Pasal 24 A ayat (1) UUD 1945 yang mengatur terkait kewenangan Mahkamah Agung, yaitu berwenang menguji peraturan secara materiil terhadap peraturan perundang-undangan di bawah Undang-undang, dan mempunyai wewenang lainnya yang diberikan oleh undang-undang. Apabila merujuk pada Undang-Undang Nomor 12 Tahun 2011 tentang Pembentukan Peraturan Perundangundangan,hierarki peraturan perundangundangan sebagaimana berikut:
1. UUD 1945
2. Tap MPR
3. Undang-Undang/Perpu
4. Peraturan Pemerintah
5. Peraturan Presiden
6. Peraturan Daerah Provinsi
7. Peraturan Daerah Kabupaten/Kota Berdasarkan pengaturan tersebut, maka pengujian terkait Peraturan Pemerintah, Perpres, Perda Prov dan Perda Kab/Kota seharusnya mutlak menjadi kewenangan Mahkamah Agung. Akan tetapi pada 
realitasnya, lembaga eksekutif, melalui Kementerian Dalam Negerijuga mempunyai kewenangan untuk menguji peraturan daerah (Perda).Putusan MK atas uji materi Nomor 56/PUU-XIV/2016 kemudian membatalkan kewenangan Mendagri untuk membatalkan Perda, dan memberikan kewenangan tersebut sepenuhnya kepada Mahkamah Agung.

Namun ternyata Putusan MK tidak serta merta menjadikan Mahkamah Agung sebagai satu-satunya lembaga yang menangani pengujian peraturan dibawah undang-undang. Kementerian Hukum dan HAM RI kemudian membuat Peraturan Menteri Hukum dan HAM Nomor 32 Tahun 2017 tentang Tata Cara Penyelesaian Sengketa Peraturan Perundang-Undangan. Melalui Jalur Nonlitigasi yang memberikan kewenangan kepada Menkumham melalui Dirjen PP untuk membentuk Tim yang bertugas melakukan penyelesaian sengketa di luar pengadilan. Rekomendasi yang dikeluarkan Tim tersebut salah satunya adalah mencabut serta merubah peraturan perundang-undangan yang disengketakan. Yang kemudian menjadi persoalan adalah apakah Kemenkumham mempunyai kewenangan untuk menjadi pengadil dalam penyelesaian sengketa sebagaimana yang dimaksud diatas.

\section{B. METODE PENELITIAN}

Penelitian dilakukan melalui penelitian hukum normatif, dengan mengkaji dan menganalisis peraturan perundangundangan atau bahan hukum lain yang berkaitan dengan Ultra Vires Kewenangan Kemenkumham sebagai Pengadilan NonLitigasi dalam Sistem Ketatanegaraan Indonesia. Penelitian hukum ini dilakukan melalui pendekatan peraturan perundangundangan (statutory approach). ${ }^{3}$ Pendekatan peraturan perundang-undangan dilakukan dengan mengkaji peraturan perundang-

\footnotetext{
3 Johni Ibrahim, Teori dan Metodologi Penelitian Hukum Normatif, (Bayumedia Publishing:Malang,2007), Hal.300
}

undangan yang terkait dengan tema penelitian.

Penelitian hukum normatif ini menggunakan jenis data sekunder atau data yang diperoleh melalui bahan kepustakaan, sehingga metode pengumpulan data dilaksanakan dengan mencari pustaka yang relevan, baik melalui perpustakaan maupun pusat data jurnal daring. Pengumpulan data sekunder yang digunakan dalam penelitian ini difokuskan pada: (a) bahan hukum primer, berupa peraturan perundang-undangan yang terkait dengan tema penelitian; dan (b) bahan hukum sekunder, berupa buku referensi dan jurnal yang terkait dengan tema penelitian dan menguraikan lebih lanjut bahan hukum primer dalam konteks teoretis dan implementasi yang relevan.

\section{KERANGKA KONSEPTUAL}

Dalam tataran dogmatika hukum, titik berat dilakukan terhadap teori pemisahan kekuasaan yang digagas oleh Montesquieu yaitu memisahkan kekuasaan menjadi tiga yaitukekuasaan legislatif (membuat undang undang), kekuasaan eksekutif (melaksanakan undang undang), kekuasaan yudikatif (mengadili bila terjadi pelanggaran terhadap undang undang). ${ }^{4}$ Sedangkan pada tataran teori hukum dilakukan telaah terhadap teoriteori yang dapat digunakan untuk menganalisis tindakan Ultra Vires (melampui kewenangan)Kementerian Hukum dan HAM RI dalam Peraturan Menteri Hukum dan HAM Nomor 32 Tahun 2017 tentang Tata Cara Penyelesaian Sengketa Peraturan Perundang-Undangan Melalui Jalur Nonlitigasi.

\section{PEMBAHASAN}

Reformasi kehakiman merupakan salah satu poin vital dalam reformasi birokrasi. Salah satu reformasi itu adalah

\footnotetext{
${ }^{4}$ Efi Yulistyowati,'Penerapan Konsep Trias Politica Dalam Sistem Pemerintahan Republik Indonesia : Studi Komparatif Atas Undang-Undang Dasar Tahun 1945 Sebelum Dan Sesudah Amandemen", Jurnal Dinamika Sosial Budaya, Nomor 2 (2018) 328-338
} 
menempatkan semua pengujian peraturan perundang-undangan di bawah kekuasaan kehakiman. Di era reformasi, Indonesia mempunyai dua lembaga peradilan yang berwenang menguji peraturan perundangundangan, yaitu Mahkamah Konstitusi dan Mahkamah Agung.

\section{Mahkamah Agung berwenang} menguji peraturan perundang-undangan di bawah undang-undang terhadap undangundang, sementara itu Mahkamah Konstitusi berwenang mengadili pada tingkat pertama dan terakhir yang putusannya bersifat final untuk menguji undang-undang terhadap Undang-Undang Dasar. ${ }^{5}$ Merujuk pada Undang-Undang Nomor 12 Tahun 2011 tentang Pembentukan Peraturan Perundangundangan, maka hierarki peraturan perundang-undangan di Indonesia sebagai berikut.

a. Undang-Undang Dasar Negara Republik IndonesiaTahun 1945;

b. Ketetapan Majelis Permusyawaratan Rakyat;

c. Undang-Undang/Peraturan

Pemerintah Pengganti Undang-Undang;

d. Peraturan Pemerintah;

e. Peraturan Presiden;

f. Peraturan Daerah Provinsi; dan

g. Peraturan Daerah Kabupaten/Kota.

Merujuk pada hierarki tersebut dan Pasal 24A UUD 1945, dengan asumsi bahwa Mahkamah Agung berwenang menguji peraturan perundang-undangan di bawah undang-undang terhadap undang-undang, maka semua peraturan baik itu Peraturan Pemerintah, Peraturan Presiden, Perda Provinsi dan Perda Kabupaten/Kota kewenangan pengujiannya dilakukan oleh Mahkamah Agung.

Namun sejak amandemen konstitusi terkait dengan kekuasaan kehakiman telah di sahkan, masih terdapat banyak aturan yang memungkinkan adanya pengujian Perda terhadap undang-undang di Kementerian Dalam Negeri. Dasar hukum pengujian

\footnotetext{
${ }^{5}$ Pasal 24 Undang-Undang Dasar 1945
}

tersebut terdapat dalam Pasal 251 UndangUndang Nomor 23 Tahun 2014 tentang Pemerintahan Daerah: ${ }^{6}$

\section{Pasal 251}

(1) Perda Provinsi dan peraturan gubernur yang bertentangan dengan ketentuan peraturan perundangundangan yang lebih tinggi, kepentingan umum, dan/atau kesusilaan dibatalkan oleh Menteri.

(2) Perda Kabupaten/Kota dan peraturan bupati/wali kota yang bertentangan dengan ketentuan peraturan perundang-undangan yang lebih tinggi, kepentingan umum, dan/atau kesusilaan dibatalkan oleh gubernur sebagai wakil Pemerintah Pusat.

(3) Dalam hal gubernur sebagai wakil Pemerintah Pusat tidak membatalkan Perda Kabupaten/Kota dan/atau peraturan bupati/wali kota yang bertentangan dengan ketentuan peraturan perundang-undangan yang lebih tinggi, kepentingan umum, dan/atau kesusilaan sebagaimana dimaksud pada ayat (2), Menteri membatalkan Perda Kabupaten/Kota dan/atau peraturan bupati/wali kota.

(4) Pembatalan Perda Provinsi dan peraturan gubernur sebagaimana dimaksud pada ayat (1) ditetapkan dengan keputusan Menteri dan pembatalan Perda Kabupaten/Kota dan peraturan bupati/wali kota sebagaimana dimaksud pada ayat (2) ditetapkan dengan keputusan gubernur sebagai wakil Pemerintah Pusat.

Berdasarkan ketentuan diatas, Pemerintah mempunyai hak untuk melakukan executive review terhadap peraturan daerah baik di tingkat kabupaten/kota maupun provinsi. Pasal ini kemudian dilakukan uji materi ke Mahkamah Konstitusi yang pada akhirnya MK melalui PutusannyaNomor 56/PUU-XIV/2016 dengan merujuk pada Putusan Nomor 137/PUU-XIII/2015 membatalkan ketentuan dalam pasal tersebut

\footnotetext{
6 M. Nur Sholikin, "Penghapusan Kewenangan Pemerintah Untuk Membatalkan Perda; Momentum Mengefektifkan Pengawasan Preventif Dan Pelaksanaan Hak Uji Materiil MA", Jurnal Rechtsvinding Online (2017)
} 
dan menyatakan bahwa Pemerintah melalui Menteri Dalam Negeri tidak berwenang untuk membatalkan Perda, yang berwenang hanyalah Mahkamah Agung.

Putusan ini seharusnya menghentikan dualisme pengujian Perda yang selama ini terjadi dalam sistem ketatanegaraan Indonesia, dimana ada dua lembaga yang mempunyai kewenangan menguji legalitas Perda, yaitu :

(1) Kementerian Dalam Negeri melalui Executive Review

(2) Mahkamah Agung melalui Judicial Review

Dalam pertimbangan hukumnya, Mahkamah Konstitusi melihat bahwa keberadaan Pasal 251 ayat (2) dan ayat (3) Undang-Undang Pemda yang memberi wewenang kepada Menteri dan Gubernur sebagai wakil Pemerintah Pusat untuk membatalkan Perda Kabupaten/Kota yang bertentangan dengan ketentuan peraturan perundang-undangan yang lebih tinggi, selain menyimpangi logika dan bangunan negara hukum Indonesia sebagaimana amanah Pasal 1 ayat (3) UUD 1945 juga menegasikan peran dan fungsi Mahkamah Agung sebagai lembaga yang berwenang melakukan pengujian peraturan perundang-undangan di bawah Undang-Undang in casu Perda Kabupaten/Kota sebagaimana ditegaskan dalam Pasal 24A ayat (1) UUD 1945. Demikian juga mengenai kepentingan umum dan/atau kesusilaan yang juga dijadikan tolok ukur dalam membatalkan Perda, menurut Mahkamah Konstitusi juga merupakan ranah Mahkamah Agung untuk menerapkan tolok ukur tersebut. Apalagi Pasal 250 ayat (1)Undang-Undang Pemda terkait dengan hal itu sudah terdapat indikator yang cukup jelas. Sesuatu dianggap bertentangan dengan kepentingan umum apabila ${ }^{7}$ :

1. terganggunya kerukunan antar warga masyarakat;

\footnotetext{
${ }^{7}$ Pertimbangan Hukum Putusan Mahkamah Konstitusi Nomor 56/PUU-XIV/2016
}

2. terganggunya akses terhadap pelayanan publik;

3. terganggunya ketentraman dan ketertiban umum;

4. terganggunya kegiatan ekonomi untuk meningkatkan kesejahteraan masyarakat; dan/atau

5. diskriminasi terhadap suku, agama, dan kepercayaan, ras, antar-golongan, dan gender.

Selain itu Mahkamah Konstitusi dalam pertimbangannya juga mencantumkan sejumlah hal sebagai berikut: ${ }^{8}$

Adapun yang dimaksud dengan kesusilaan menurut Penjelasan Pasal 250 ayat (1) UU Pemda adalah norma yang berkaitan dengan adab dan sopan santun, kelakuan yang baik, dan tata krama yang luhur.

Bahwa pembatalan Perda Kabupaten/Kota melalui keputusan gubernur sebagai wakil Pemerintah Pusat sebagaimana dimaksud dalam Pasal 251 ayat (4) UU Pemda, menurut Mahkamah tidak sesuai dengan rezim peraturan perundangundangan yang dianut Indonesia. Pasal 7 ayat (1) dan Pasal 8 UU $12 / 2011$ tidak mengenal keputusan gubernur sebagai salah satu jenis dan hierarki peraturan perundang-undangan. Dengan demikian kedudukan keputusan gubernur bukanlah bagian dari rezim peraturan perundangundangan, sehingga tidak dapat dijadikan produk hukum untuk membatalkan Perda Kabupaten/Kota. Dengan kata lain, menurut Mahkamah terjadi kekeliruan dimana Perda Kabupaten/Kota sebagai produk hukum yang berbentuk peraturan (regeling) dapat dibatalkan

\footnotetext{
${ }^{8}$ Ibid
} 
dengan keputusan gubernur sebagai produk hukum yang berbentuk keputusan (beschikking). Selain itu, ekses dari produk hukum pembatalan Perda dalam lingkup eksekutif dengan produk hukum ketetapan gubernur sebagaimana ditentukan dalam Pasal 251 ayat (4) UU Pemda berpotensi menimbulkan dualisme putusan pengadilan jika kewenangan pengujian atau pembatalan Perda terdapat pada lembaga eksekutif dan lembaga yudikatif.

Dalam hal Perda Kabupaten/Kota dibatalkan melalui keputusan gubernur upaya hukum yang dilakukan adalah melalui Pengadilan Tata Usaha Negara (PTUN) dan seandainya upaya hukum tersebut dikabulkan maka Perda Kabupaten/Kota yang dibatalkan oleh keputusan gubenur menjadi berlaku kembali. Di sisi lain, terdapat upaya hukum pengujian Perda melalui Mahkamah Agung yang dilakukan oleh Pemerintah, masyarakat di daerah tersebut atau pihak yang merasa dirugikan dengan berlakunya Perda tersebut. Misalnya upaya hukum melalui Mahkamah Agung tersebut dikabulkan maka Perda menjadi dinyatakan tidak berlaku. Dengan demikian telah terjadi dualisme dalam persoalan yang sama. Potensi dualisme putusan pengadilan antara putusan PTUN dan putusan pengujian Perda oleh Mahkamah Agung terhadap substansi perkara yang sama, hanya berbeda produk hukum akan menimbulkan ketidakpastian hukum, padahal kepastian hukum merupakan hak setiap orang yang dijamin dan dilindungi oleh Pasal
28D ayat (1) UUD 1945. Oleh

karena itu, demi kepastian hukum dan sesuai dengan UUD 1945 menurut Mahkamah pengujian atau pembatalan Perda menjadi ranah kewenangan konstitusional Mahkamah Agung.

Terlihat dari pertimbangan hukum Putusan MK tersebut diatas, ada dua poin yang menjadi alasan ketentuan terkait pembatalan Perda oleh Pemerintah menjadi inkonstitusional, yaitu:

1. Mencegah adanya benturan antara Putusan pengadilan (judicial power) dan keputusan pemerintah (executive power)

2. Sebagai alat untuk mencegah dualisme putusan Pengadilan ekses sebagai pembatalan Perda, karena Pembatalan Perda dilakukan melalui Keputusan (beschikking) dan bisa diajukan gugatan ke Pengadilan Tata Usaha Negara. Sehingga berpotensi adanya putusan pengadilan yang berbeda yaitu Putusan PTUN dan Mahkamah Agung.

\section{Kewenangan Menkumham melalui Permenkumham Nomor 32 Tahun 2017}

Setelah adanya Putusan MK yang menjadikan pengujian Perda melalui satu pintu, Menteri Hukum dan HAM RI kemudian mengeluarkan Peraturan Menteri Hukum dan HAM Nomor 32 Tahun 2017 tentang Tata Cara Penyelesaian Sengketa Peraturan Perundang-UndanganMelalui Jalur Nonlitigasi yang didalamnya terdapat sejumlah kewenangan Menkumham yang berkaitan dengan pengujian Perda.

Dalam diktummenimbang dikeluarkannya Permenkumham, terdapat frase sebagai berikut: ${ }^{9}$

"bahwa dalam penyelenggaraan pemerintahan ditemukan peraturan perundang-undangan yang saling bertentangan baik

${ }^{9} \mathrm{Ibid}$ 
secara vertikal maupun horizontal yang menyebabkan timbulnya konflik norma hukum, konflik kewenangan antarkementerian/lembaga dan pemerintah daerah, menimbulkan ketidakadilan bagimasyarakat dan pelaku usaha, serta menghambat iklim investasi, usaha, dan kegiatan ekonomi nasional dan daerah di Indonesia;",

"bahwa untuk menegakkan prinsip penyelenggaraan pemerintahan berdasarkan hukum dan untuk mengatasi kondisi sebagaimana dimaksud dalam huruf a dan huruf $b$, perlu mengatur tata cara penyelesaian sengketa peraturan perundangundangan melalui jalur nonlitigasi;"

Terlihat dalam diktum menimbang nya, Permenkumham ini memang memberikan kewenangan kepada Menteri Hukum dan HAM RI untuk melakukan koreksi terhadap peraturan perundangundangan yang bertentangan baik secara vertikal maupun horizontal yang menimbulkan ketidakadilan bagi masyarakat dan pelaku usaha serta menghambat iklim investasi, usaha dan kegiatan ekonomi nasional. Padahal apabila kita membandingkan diktum menimbang tersebut dengan pertimbangan hukum dalam putusan MK maka terdapat beberapa hal yang kontradiktif:

\section{Tabel 1}

Komparasi Diktum Menimbang dalam Permenkumham dan Pertimbangan Hukum dalam Putusan MK

\begin{tabular}{|c|l|}
\hline \multicolumn{1}{|c|}{$\begin{array}{c}\text { Diktum Menimbang } \\
\text { Permenkumham }\end{array}$} & $\begin{array}{c}\text { Pertimbangan } \\
\text { Hukum Putusan } \\
\text { MK }\end{array}$ \\
\hline $\begin{array}{l}\text { Adanya peraturan } \\
\text { perundang-undangan yang } \\
\text { saling bertentangan baik } \\
\text { secara vertikal maupun }\end{array}$ & $\begin{array}{l}\text { Menurut MK } \\
\text { mengenai } \\
\text { kepentingan } \\
\text { umum dan/atau }\end{array}$ \\
\hline
\end{tabular}

\begin{tabular}{|l|l|}
\hline horizontal yang & kesusilaan yang \\
menyebabkan timbulnya & juga dijadikan \\
konflik norma hukum, & tolok ukur \\
konflik kewenangan & dalam \\
antarkementerian/lembaga & membatalkan \\
dan pemerintah daerah, & Perda \\
menimbulkan ketidakadilan & sebagaimana \\
bagi masyarakat dan pelaku & termuat dalam \\
usaha, serta menghambat & Pasal 251 ayat \\
iklim investasi, usaha, dan & $(2)$ dan ayat (3) \\
kegiatan ekonomi nasional & UU Pemda, \\
dan daerah di Indonesia, & menurut dibuatlah \\
maka & Mahkamah juga \\
Permenkumham. & merupakan \\
& ranah \\
& Mahkamah \\
& Agung untuk \\
& menerapkan \\
tolok ukur \\
tersebut, bukan
\end{tabular}

Sumber : diolah dari berbagai sumber

Apabila membaca dalam diktum menimbang Permenkumham Nomor 32 Tahun 2017 terlihat bahwa Peraturan ini dilahirkan sebagai upaya untuk menghindari adanya peraturan perundangan-undangan dibawah undang-undang yang menimbulkan ketidakadilan bagi masyarakat, padahal dalam pertimbangan hukum Putusan MK Nomor 56/PUU-XIV/2016 sudah disebutkan bahwa terkait kepentingan umum yang dijadikan tolok ukur dalam pembatalan Perda bukanlah kewenangan Pemerintah melainkan Mahkamah Agung.

Salah satu pasal yang kemudian menjadi persoalan adalah pada pasal 6 Permenkumham Nomor 32 Tahun 2017, ${ }^{10}$

\section{Pasal 6}

(1) Berdasarkan hasil pemeriksaan permohonan sebagaimana dimaksud dalam Pasal 5, Direktur Jenderal menyampaikan laporan hasil pemeriksaan secara tertulis kepada:

\footnotetext{
${ }^{10}$ Peraturan Menteri Hukum dan HAM Nomor 32 Tahun 2017 tentang Tata Cara Penyelesaian Sengketa Peraturan Perundang-Undangan Melalui Jalur Nonlitigasi
} 

a. Menteri;
b. pemohon; dan
c. badan/lembaga/kementerian/lembaga pemerintah nonkementerian/pemerintahan daerah terkait.

(2) Menteri menyampaikan laporan hasil pemeriksaan sebagaimana dimaksud pada ayat (1) kepada Presiden disertai dengan rekomendasi.

(3) Rekomendasi sebagaimana dimaksud pada ayat (2) dapat berupa:
a. mencabut Peraturan Perundang- undangan;
b. mengubah Peraturan Perundang- undangan; atau
c. membentuk Peraturan Perundang- undangan baru.

Pada pasal ini disebutkan bahwa Direktur Jenderal Peraturan perundangundangan menyampaikan laporan rekomendasi hasil pemeriksaan secara tertulis kepada Menteri yang mana rekomendasinya dapat berupa mencabut, mengubah atau membentuk peraturan perundang-undangan yang baru.

Yang menjadi persoalan adalah terkait kewenangan Dirjen Peraturan Perundangundangan untuk memberi rekomendasi mencabut, mengubah dan membentuk peraturan perundang-undangan yang baru.

\section{Ultra Vires Kewenangan Menkumham terkait Pengujian Perda}

Dalam hukum administrasi negara Perancis, ultra vires diartikan dengan, "that every public officer has marked out for him by law a certain area of "jurisdiction". Within the boundaries of this area he can act freely according to his own discretion, and the courts will respect his action as final and not inquire into its rightfulness. But if he oversteps those bounds, the the courts will intervene. In this form, the law of court review of public officers become simply a branch of law of ultra vires. The only question before the court is one of jurisdiction, and the court has no control of the officers exercise of discretion within that jurisdiction. ${ }^{11}$ Ultra Vires dapat diartikan juga dengan melampui kewenangan.

Terkait dengan artikel inimerupakan kewenangan Kementerian Hukum dan HAM RI khususnya Direktorat Jenderal Perundangundangan, adalah mengeluarkan rekomendasi untuk mencabut, mengubah dan membentuk peraturan perundang-undangan yang baru. Apabila merujuk pada tahun dikeluarkannya Permenkumham Nomor 32 Tahun 2017, peraturan tersebut secara resmi diundangkan pada tanggal 8 Desember 2017, sehingga rujukan yang digunakan adalah Peraturan Menteri Hukum Dan Hak Asasi Manusia Republik Indonesia Nomor 29 Tahun 2015 Tentang Organisasi Dan Tata Kerja Kementerian Hukum Dan Hak Asasi Manusia Republik Indonesia.

Apabila merujuk pada pasal 141 Peraturan Menteri Hukum dan HAM RI Nomor 29 Tahun 2015, berbunyi sebagai berikut: ${ }^{12}$

Direktorat Jenderal Peraturan Perundang-undangan menyelenggarakan fungsi:

a. perumusan kebijakan dibidang perancangan, harmonisasi, pengundangan dan publikasi, litigasi peraturan perundang-undangan, fasilitasi perancangan peraturan perundang-undangan di daerah sesuai permintaan daerah, dan pembinaan perancang peraturan perundang-undangan;

b. pelaksanaan kebijakan dibidang perancangan, harmonisasi, pengundangan dan publikasi, litigasi peraturan perundang-undangan, fasilitasi perancangan peraturan

\footnotetext{
${ }^{11}$ Bernard Schwartz, French Administrative Law and the Common-law World, New Jersy:The Lawbook Exchange, Hal.200

${ }^{12}$ Peraturan Menteri Hukum Dan Hak Asasi Manusia Republik Indonesia Nomor 29 Tahun 2015 Tentang Organisasi Dan Tata Kerja Kementerian Hukum Dan Hak Asasi Manusia Republik Indonesia
} 
perundang-undangan di daerah sesuai permintaan daerah, dan pembinaan perancang peraturan perundang-undangan;

c. pemberian bimbingan teknis dan supervisi di bidang perancangan,harmonisasi,pengundang an dan publikasi, litigasi peraturanperundang-undangan,

fasilitasi perancangan peraturan perundang-undangan di daerah sesuai permintaan daerah, dan pembinaanperancang peraturan perundang-undangan;

d. pelaksanaan pemantauan, evaluasi, dan pelaporan di bidangperancangan, harmonisasi, pengundangan dan publikasi, litigasiperaturan perundangundangan, fasilitasi perancangan peraturanperundang-undangan di daerah sesuai permintaan daerah, dan pembinaan perancang peraturan perundang-undangan;

e. pelaksanaan administrasi Direktorat Jenderal Peraturan Perundangundangan; dan,

f. pelaksanaan fungsi lain yang diberikan oleh Menteri.

Sementara itu terkait tugas pokok dan fungsi Direktorat Litigasi ;

\section{Pasal 266}

Dalam melaksanakan tugas sebagaimana dimaksud dalam Pasal 265, Direktorat Litigasi Peraturan Perundang-undangan menyelenggarakan fungsi:

a. penyiapan perumusan kebijakan di bidang litigasi peraturanperundangundangan;

b. pelaksanaan kebijakan teknis di bidang litigasi peraturan perundang-undangan;

c. pemberian bimbingan teknis dan supervisi di bidang litigasi peraturan perundangundangan;

d. pelaksanaan pemantauan, evaluasi dan pelaporan di bidanglitigasiperaturan perundang-undangan; dan e. pelaksanaan urusan tata usaha dan rumah tangga DirektoratLitigasiPeraturan Perundang-undangan

Pada tanggal 23 Agustus 2018, Menteri Hukum dan HAM RI kemudian mengeluarkan Peraturan Menteri Hukum Dan Hak Asasi Manusia Republik Indonesia Nomor 24 Tahun 2018 Tentang Perubahan Ketiga Atas Peraturan Menteri Hukum Dan Hak Asasi Manusia Nomor 29 Tahun 2015 Tentang Organisasi Dan Tata Kerja Kementerian Hukum Dan Hak Asasi Manusia Republik Indonesia yang dalam isinya memberikan kewenangan baru terhadap Direktorat Jenderal Peraturan Perundangundangan terutama Direktorat Litigasi untuk menyelesaikan sengketa peraturan perundangundangan. $^{13}$

\section{Pasal 265}

Direktorat Litigasi Peraturan Perundangundangan mempunyai tugas melaksanakan penyiapan perumusan dan pelaksanaan kebijakan, pemberian bimbingan teknis dan supervisi, serta pelaksanaan pemantauan, evaluasi dan pelaporan di bidang litigasi peraturan perundang-undangan dan penyelesaian sengketa peraturan perundangundangan di luar pengadilan sesuai dengan kebijakan teknis yang ditetapkan oleh Direktorat Jenderal Peraturan Perundangundangan.

Dalam Peraturan Menteri tersebut diatas, Kemenkumham secara tidak langsung memperluas kewenangannya sendiri yang tidak ada di Peraturan Menteri sebelumnya. Hanya saja yang kemudian menjadi catatan, kewenangan tersebut sudah ada terlebih dahulu pada Peraturan Menteri Hukum dan HAM Nomor 32 Tahun 2017 tentang Tata Cara Penyelesaian Sengketa Peraturan Perundang-Undangan Melalui Jalur Nonlitigasi baru kemudian dibuat dasar hukumnya pada Peraturan Menteri Hukum Dan Hak Asasi Manusia Republik Indonesia Nomor 24 Tahun 2018 Tentang Perubahan Ketiga Atas Peraturan Menteri Hukum Dan

\footnotetext{
${ }^{13}$ Ibid
} 
Hak Asasi Manusia Nomor 29 Tahun 2015

Tentang Organisasi Dan Tata Kerja Kementerian Hukum Dan Hak Asasi Manusia Republik Indonesia.

Terlihat dalam ketentuan ini terdapat aturan yang sebenarnya dilanggar oleh Menkumham dalam penerbitan Peraturan Menteri Hukum dan HAM Nomor 32 Tahun 2017 tentang Tata Cara Penyelesaian Sengketa Peraturan Perundang-Undangan Melalui Jalur Nonlitigasi, karena sebelumnya tidak adanya kewenangan bagi Kemenkumham untuk mengadili sengketa non litigasi dalam Peraturan Menteri Hukum Dan Hak Asasi Manusia Nomor 29 Tahun 2015 Tentang Organisasi Dan Tata Kerja Kementerian Hukum Dan Hak Asasi Manusia Republik Indonesia. Peraturan yang menjadi dasar kewenangan tersebut baru diadakan pada tahun 2018 sementara praktek itu sudah dilakukan satu tahun sebelumnya.

\section{Potensi Inkonstitusionalitas}

\section{Permenkumham Nomor 32 Tahun 2017}

Mahkamah Konstitusi dalam putusannya sudah sangat jelas memisahkan kewenangan antara kekuasaan eksekutif dan yudikatif. ${ }^{14}$

"...Bahwa keberadaan Pasal 251 ayat (2) dan ayat (3) UU Pemda yang memberi wewenang kepada Menteri dan gubernur sebagai wakil Pemerintah Pusat untuk membatalkan Perda Kabupaten/Kota yang bertentangan dengan ketentuan peraturan perundang-undangan yang lebih tinggi, selain menyimpangi logika dan bangunan negara hukum Indonesia sebagaimana amanah Pasal 1 ayat (3) UUD 1945 juga menegasikan peran dan

\footnotetext{
${ }^{14}$ Putusan Mahkamah Konstitusi Nomor 56/PUUXIV/2016 tanggal 15 Juni 2017
}

fungsi Mahkamah Agung sebagai lembaga yang berwenang melakukan pengujian peraturan perundang-undangan di bawah Undang-Undang in casu Perda Kabupaten/Kota sebagaimana ditegaskan dalam Pasal 24A ayat (1) UUD 1945. Demikian juga mengenai kepentingan umum dan/atau kesusilaan yang juga dijadikan tolok ukur dalam membatalkan Perda sebagaimana termuat dalam Pasal 251 ayat (2) dan ayat (3) UU Pemda, menurut Mahkamah juga merupakan ranah Mahkamah Agung untuk menerapkan tolok ukur tersebut, selain ketentuan peraturan perundangundangan yang lebih tinggi, dikarenakan telah termuat dalam undang-undang, sehingga juga dapat dijadikan batu uji oleh Mahkamah Agung dalam mengadili pengujian Perda. Pasal 250 ayat (1) UU Pemda menyatakan bertentangan dengan kepentingan umum meliputi: 1. terganggunya kerukunan antar warga masyarakat; 2 terganggunya akses terhadap pelayanan publik; 3 . terganggunya ketentraman dan ketertiban umum; 4 . terganggunya kegiatan ekonomi untuk meningkatkan kesejahteraan masyarakat; dan/atau 5 . diskriminasi terhadap suku, agama, dan kepercayaan, ras, antar-golongan, dan 
gender. Adapun yang dimaksud dengan kesusilaan menurut Penjelasan Pasal 250 ayat (1) UU Pemda adalah norma yang berkaitan dengan adab dan sopan santun, kelakuan yang baik, dan tata krama yang luhur.

Terlihat dalam pertimbangan hukumnya putusan MK, satu-satunya lembaga yang mempunyai kewenangan untuk menafsirkan terkait adanya pelanggaran kepentingan umum dan/atau kesusilaan bukan lembaga eksekutif. Oleh karena itu keberadaan Peraturan Menteri yang memberikan kewenangan kepada Menteri Hukum dan HAM RI melalui Direktorat Jenderal Peraturan Perundang-undangan untuk mengadili sengketa peraturan perundang-undangan melalui jalur non litigasi pada dasarnya tidak berbeda dengan proses executive review atau peninjauan peraturan perundang-undangan yang dilakukan oleh Menteri Dalam Negeri berdasarkan UndangUndang Nomor 25 tahun 2014 tentang Pemerintahan Daerah.

Apalagi terkait dengan kewenangan Kementerian Hukum dan HAM RI untuk mengadili sengketa diawali dengan kemunculan Permenkumham dulu baru kemudian dimunculkan kewenangannya sebagaidasar hukumnya terkait dengan Orta yang menambah kewenangan Direktorat Jenderal Peraturan Perundang-undangan. Oleh karena itu secara norma pembentukannya, Kemenkumham telah melampui kewenangannya sendiri yang diatur dalam peraturan perundang-undangan.

Terkait dengan keberadaan Peraturan Menteri Hukum Dan Hak Asasi Manusia Republik Indonesia Nomor 24 Tahun 2018 Tentang Perubahan Ketiga Atas Peraturan Menteri Hukum Dan Hak Asasi Manusia Nomor 29 Tahun 2015 Tentang Organisasi Dan Tata Kerja Kementerian Hukum Dan Hak Asasi Manusia Republik Indonesia yang memberikan kewenangan kepada Menteri
Hukum dan HAM untuk menyelesaikan sengketa peraturan perundang-undangan juga inkonstitutional, karena berdasarkan pada Putusan Mahkamah Konstitusi kewenangan tersebut bukanlah kewenangan lembaga eksekutif melainkan lembaga yudikatif yang dalam konteks ini adalah Mahkamah Agung.

\section{E. PENUTUP}

Peraturan Menteri Hukum dan HAM Nomor 32 Tahun 2017 tentang Tata Cara Penyelesaian Sengketa Peraturan PerundangUndangan Melalui Jalur Nonlitigasi merupakan salah satu produk hukum yang melanggar asas hukum larangan untuk melakukan tindakan ultra vires atau melampui kewenangan. Dalam hal ini Menteri Hukum dan HAM RI telah melakukan tindakan ultra vires.Hal itu disebabkan oleh beberapa hal, yang pertama kewenangan itu baru diadakan oleh Menteri Hukum dan HAM RI melalui Peraturan Menteri Hukum dan HAM RI Nomor 24 Tahun 2018 Tentang Perubahan Ketiga Atas Peraturan Menteri Hukum Dan Hak Asasi Manusia Nomor 29 Tahun 2015 Tentang Organisasi Dan Tata Kerja Kementerian Hukum Dan Hak Asasi Manusia Republik Indonesia yang mana berarti kewenangan itu pada awalnya belum ada pada tahun 2017 ketika dikeluarkannya Peraturan Menteri Nomor 32 Tahun 2017 . Kedua, adanya Putusan MK yang dalam pertimbangan hukumnya sudah jelas mengatakan bahwa yang berhak menentukan tolok ukur suatu peraturan perundang-undangan menimbulkan ketidakadilan bagi masyarakat dan pelaku usaha, serta menghambat iklim investasi, usaha, dan kegiatan ekonomi nasional dan daerah di Indonesia adalah lembaga yudikatif atau Mahkamah Agung bukan Menteri Hukum dan HAM sebagai lembaga eksekutif.

Berdasarkan fakta-fakta tersebut diatas serta adanya ketentuan bahwa Putusan MK adalah final dan mengikat maka Pemerintah tidak mempunyai kewenangan untuk melakukan review terhadap peraturan perundang-undangan, sehingga jauh lebih 
baik Permenkumham tersebut dicabut atau diajukan Judicial Review ke Mahkamah Agung oleh pihak-pihak yang dirugikan terhadap keberadaan Permenkumham Nomor 32 Tahun 2017.

\section{Buku}

\section{DAFTAR PUSTAKA}

Schwartz, Bernard. French Administrative Law and the Common-law World. New Jersey:The Lawbook Exchange, 1954.

Mahfud MD, Moh.Politik Hukum di Indonesia. Jakarta : PT.Raja Grafindo Persada, 2010.

Ibrahim, Johni. Teori dan Metodologi Penelitian Hukum Normatif. Malang: Bayumedia Publishing,2007.

\section{Jurnal}

Sholikin,M. Nur. "Penghapusan Kewenangan Pemerintah Untuk Membatalkan Perda; Momentum Mengefektifkan Pengawasan Preventif Dan Pelaksanaan Hak Uji Materiil MA“, Jurnal Rechtsvinding Online (2017).

Yulistyowati,Efi."Penerapan Konsep Trias Politica Dalam Sistem Pemerintahan Republik Indonesia : Studi Komparatif Atas Undang-Undang Dasar Tahun 1945 Sebelum Dan Sesudah Amandemen",Jurnal Dinamika Sosial Budaya, no.2 (2018): 328-338.

\section{Peraturan Perundang-undangan}

Undang-Undang Nomor 23 Tahun 2014 tentang Pemerintahan Daerah

Undang-Undang Nomor 4 Tahun 2004 tentang Kekuasaan Kehakiman

Peraturan Menteri Hukum dan HAM Nomor 32 Tahun 2017 tentang Tata Cara Penyelesaian Sengketa Peraturan Perundang-Undangan Melalui Jalur Nonlitigasi

Peraturan Menteri Hukum Dan Hak Asasi Manusia Nomor 29 Tahun 2015 Tentang Organisasi Dan Tata Kerja Kementerian Hukum Dan Hak Asasi Manusia Republik Indonesia
Peraturan Menteri Hukum Dan Hak Asasi Manusia Republik Indonesia Nomor 24 Tahun 2018 Tentang Perubahan Ketiga Atas Peraturan Menteri Hukum Dan Hak Asasi Manusia Nomor 29 Tahun 2015 Tentang Organisasi Dan Tata Kerja Kementerian Hukum Dan Hak Asasi Manusia Republik Indonesia 